\title{
Inhibitory effects of sigma-2 receptor agonists on T lymphocyte activation
}

\author{
Miguel A. Iñiguez ${ }^{1}$, Carmen Punzón ${ }^{1}$, Raquel Nieto ${ }^{1}$, Javier Burgueño ${ }^{2}$, José M. Vela² and Manuel Fresno ${ }^{1 *}$ \\ Departamento de Biología Molecular and Instituto de Investigación Sanitaria Princesa, Centro de Biología Molecular Severo Ochoa (CSIC-UAM), Universidad \\ Autónoma de Madrid, Nicolás Cabrera, Madrid, Spain \\ ${ }^{2}$ Laboratorios Esteve, Barcelona, Spain
}

\section{Edited by:}

Xuanwen Li, University of

Pennsylvania, USA

\section{Reviewed by:}

Xuanwen Li, University of

Pennsylvania, USA

Guangrui Yang, University of

Pennsylvania, USA

*Correspondence:

Manuel Fresno, Centro de Biología Molecular Severo Ochoa (CSIC-UAM).

Universidad Autónoma de Madrid,

Nicolás Cabrera, 1, Cantoblanco,

28049 Madrid, Spain.

e-mail:mfresno@cbm.uam.es
Sigma $(\sigma)$ receptor ligands are essentially known for their effects on the nervous system although recent studies have shown their potential effects modulating some other pathophysiological processes as cell proliferation, cancer, and the immune response. Here, we have analyzed the actions of $\sigma-1$ and $\sigma-2$ receptors ligands on T cell activation. Our results show that treatment of Jurkat T cells with $\sigma-2$ agonists decreased the induction of the expression of Interleukin (IL)-2, Tumor necrosis factor (TNF)- $\alpha$, and Cyclooxygenase (COX)-2 by activated $T$ cells in a dose-dependent manner. These effects take place at the transcriptional level since $\sigma-2$ agonists BD-737 and CB-184 diminished the activity of the promoters of those genes. Those immunosuppressive effects could be attributable to interference with transcription factor activation. Induced transcription mediated by Nuclear factor (NF)$\kappa B$ or Nuclear Factor of Activated T cells (NFAT) was inhibited by $\sigma-2$ agonists. These effects seem to be specific for $\sigma-2$ agonists as no significant effects on T cell activation by $\sigma-1$ ligands PRE-084 and BD-1063 were found. Our results provide new insights into the immunomodulatory actions of $\sigma$ ligands and describe a new property of $\sigma-2$ agonists, through inhibition of activation of transcription factors as NFAT by which these compounds are regulating gene expression. This may have important consequences on the possible therapeutic use of those compounds.

Keywords: T lymphocytes, sigma receptor, transcriptional regulation, nuclear factor of activated T cells, nuclear factor-kB

\section{INTRODUCTION}

Sigma $(\sigma)$ receptors were originally identified as members of the family of opioid receptors. Pharmacological studies have identified two subtypes of $\sigma$ receptors, named $\sigma-1$ and $\sigma-2$ (reviewed in; Bowen, 2000; Su and Hayashi, 2003; Guitart et al., 2004). However, their endogenous ligands still remains unknown. Moreover, it has not been well defined which are the signal transduction pathways triggered by those receptors. Whereas the gene encoding the $\sigma-1$ receptor has been cloned and characterized (Hanner et al., 1996), the molecular nature of the $\sigma-2$ receptor is still not clearly defined. A recent report has identified the progesterone receptor membrane component 1 (PGRMC1) protein as the putative sigma-2 receptor (Xu et al., 2011). Sigma receptor ligands have been widely investigated for the treatment of brain related disorders (Bowen, 2000; Guitart et al., 2004) although recent studies have attributed to $\sigma-1$ and $\sigma-2$ ligands a therapeutic role in other pathologies as inflammatory diseases and cancer (Bourrie et al., 2004; Megalizzi et al., 2010; van Waarde et al., 2010).

\footnotetext{
Abbreviations: COX, Cyclooxygenase; CsA, Cyclosporin A; Ion, A23187 calcium ionophore; FBS, fetal bovine serum; GAPDH, glyceraldehyde 3 phosphate dehydrogenase; IL, interleukin; Luc, luciferase; NFAT, nuclear factor of activated T cells; NFкB, nuclear factor «B; PBTs, peripheral blood T lymphocytes; PG, prostaglandin; PMA, phorbol 12-myristate 13-acetate; SD, standard deviation; TCR, T cell receptor; TNF tumor necrosis factor.
}

These receptors are mainly expressed in a variety of distinct regions of the central nervous system but recent reports have also shown significant levels of sigma receptors in immune tissues. Thus, high-affinity $\sigma$ receptors have been identified in human peripheral blood mononuclear cells (Su et al., 1988; Wolfe et al., 1988) and rat and mouse spleen (Carr et al., 1991; Liu et al., 1995) using selective radio-ligands. Although involvement of $\sigma$ receptors in the regulation of inflammation and the immune response have been reported, few studies have addressed the selective effect of $\sigma-1$ and $\sigma-2$ ligands (either agonists or antagonists) on immune function so far. Most of the studies have been performed with dual $\sigma-1$ and $\sigma-2$ ligands, as SR31747, which binds with high-affinity to human and rat leukocytes and exhibit immunosuppressive properties in vitro and in vivo. This ligand suppresses mitogen-induced proliferation of mouse and human lymphocytes (Casellas et al., 1994) and stimulates LPS- or staphylococcal enterotoxin B-induced Interleukin (IL)10 serum release, while concomitantly inhibiting Tumor necrosis factor (TNF)- $\alpha$ production "in vivo"(Bourrie et al., 1995, 1996; Derocq et al., 1995). "In vitro" studies have shown that SR31747A induces IL-10 and reduces nitric oxide synthesis in LPS-stimulated macrophages (Gannon et al., 2001). In addition, SR31747 blocked LPS-induced production of cytokines IL-1, IL-6, and TNF $\alpha$ in a dose-dependent manner "in vitro" but not "in vivo" (Derocq et al., 1995). SR31747 inhibits both delayed-type hypersensitivity 
granuloma and graft-versus-host reaction (Casellas et al., 1994). Moreover, SR31747 impairs activation of T cells and reduces IFN- $\gamma$ and GM-CSF gene expression, while it barely alters IL-4 gene expression (Carayon et al., 1995). SR125329A, a $\sigma-1 / \sigma-2$ ligand, which is also a human sterol isomerase ligand, inhibited staphylococcal enterotoxin B-induced mouse splenocyte proliferation (Bourrie et al., 2002) and enhanced LPS-induced systemic release of IL-10 while simultaneously inhibiting TNF- $\alpha$ synthesis. It also prevented graft-versus-host disease (Bourrie et al., 2002). Cocaine has been reported to act as $\sigma-1$ receptor ligand being able to modulate immune function in vivo and in vitro (Pellegrino and Bayer, 1998; Xu et al., 1999). Thus, cocaine modulates cytokine production by human peripheral blood lymphocytes, down-regulating the production of IFN- $\gamma$, and IL- 6 in leukocytes and increasing the production of TGF- $\beta$ by macrophages (Mattana et al., 1994; Mao et al., 1996, 1997) and IL-10 by splenocytes (Zhu et al., 2003), Nonetheless, some results suggest that the immunomodulatory effects of cocaine may be mediated, in part, by modification of endothelial-derived cytokine production (Mao et al., 1997). Thus, although several reports have addressed the anti-inflammatory and immunosuppressive activity of $\sigma$ ligands in leukocytes, the molecular mechanisms responsible for the actions of $\sigma$ ligands selective for the $\sigma-1$ or $\sigma-2$ receptor in T cells, remain unknown.

Activation of $\mathrm{T}$ cells triggers a complex regulatory cascade of events leading to activation of transcription factors including Nuclear Factor of Activated T Cells (NFAT) and Nuclear Factor $(\mathrm{NF})-\kappa \mathrm{B}$, that culminates in the induced transcription of a variety of activation-associated genes that in turn, regulate cell proliferation, differentiation, and acquisition of effectors functions by cells of the immune system (Altman et al., 1990; Ullman et al., 1990; Weiss and Littman, 1994). NFAT proteins are involved in the regulation of the transcriptional induction of a variety of genes that are essential in the immune and inflammatory response such as cytokines (IL-2, IL-4, IL-13, GM-CSF, TNF $\alpha$ ), pro-inflammatory genes (COX-2), and cell surface receptors (FasL, CD40L; Rao et al., 1997; Crabtree, 1999; Iniguez et al., 2000).

Here, we have analyzed a panel of $\sigma-1$ and $\sigma-2$ ligands (either agonists or antagonists) in $\mathrm{T}$ cell function in vitro showing that treatment with $\sigma-2$ agonists interferes with $\mathrm{T}$ cell activation and cytokine gene expression. Our findings suggest that $\sigma-2$ agonists display immunomodulatory and anti-inflammatory actions through the inhibition of NFATdependent transcription, leading to down-regulation of $\mathrm{T}$ cell activation.

\section{MATERIALS AND METHODS CELL CULTURE}

The Jurkat human leukemic $\mathrm{T}$ cell line was grown in complete RPMI 1640 medium, supplemented with 10\% Fetal Bovine Serum (FBS), $2 \mathrm{mM}$ Glutamine and antibiotics. Purified human peripheral blood $\mathrm{T}$ lymphocytes (PBTs) were obtained from partially purified human blood by FicollHypaque gradient as previously described (Iniguez et al., 1999). Cells were stimulated with Phorbol 12-myristate 13acetate (PMA; Sigma-Aldrich; $15 \mathrm{ng} / \mathrm{ml}$ ), A23187 calcium ionophore (Ion; Sigma); (1 $\mu \mathrm{M})$. Sigma ligands: PRE-O84 2-(4Morpholinethyl) 1-phenylcyclohexanecarboxylate ( $\sigma-1$ agonist; Tocris; Su et al., 1991); BD-1063 1-[2-(3,4-Dichlorophenyl)ethyl]4-methylpiperazine ( $\sigma-1$ antagonist; Tocris; Matsumoto et al., 1995); BD-737 (1S,2R)-cis-N-[2-(3,4-dichlorophenyl)ethyl]-Nmethyl-2-(1-pyrrolidinyl)-cyclohexylamine (Bowen et al., 1992) and CB-184 -1R, 5R-(E)-8-(3,4-dichlorobenzylidene)-5-(3hydroxyphenyl)-2-methylmorphan-7-one ( $\sigma-2$ agonists; Bowen et al., 1995) and; AC-927 N-phenethylpiperidine oxalate $(\sigma-2$ antagonist; Berardi et al., 2004), were synthesized by Laboratories Esteve. These compounds were dissolved in DMSO and tested over a range of concentrations $(0.1-10 \mu \mathrm{M})$. Cyclosporin A (CsA, $100 \mathrm{ng} / \mathrm{ml}$; Sigma-Aldrich) or $\sigma$ ligands were added $1 \mathrm{~h}$ prior PMA + Ion stimulation.

\section{mRNA ANALYSIS}

Total RNA was prepared from cells by the TRIzol reagent RNA protocol (Invitrogen). For standard RT-PCR, RNA ( $1 \mu \mathrm{g})$ was reverse transcribed by the RNA PCR core kit (PerkinElmer). cDNA was used for PCR amplification to analyze gene expression by standard RT-PCR using specific primers for $\sigma$-1sense $\left(5^{\prime}\right.$-CTGGATGGGCGCCATGTG- $\left.3^{\prime}\right)$; $\sigma$-1-antisense

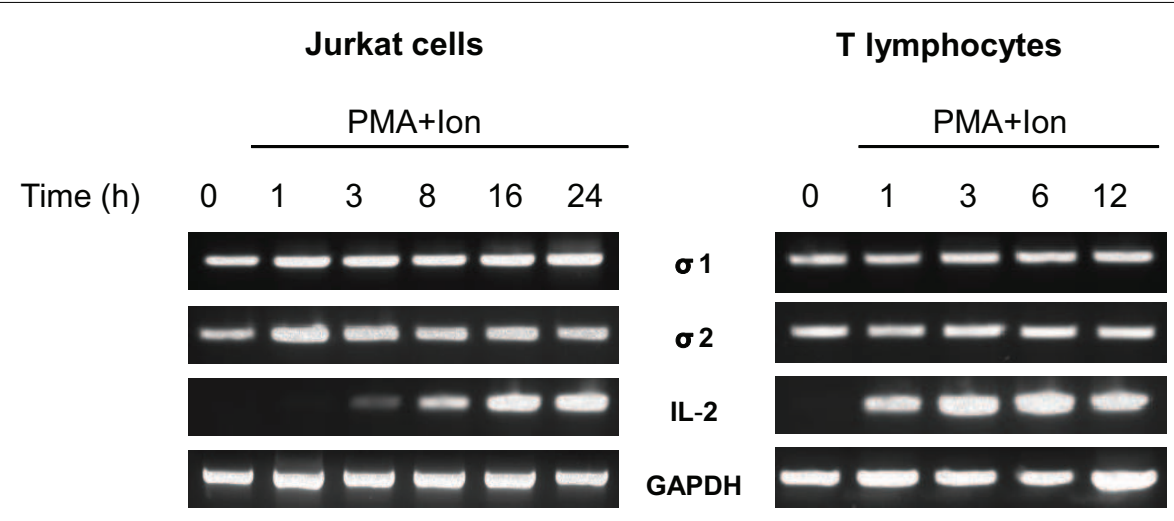

FIGURE 1 | Expression of $\sigma$ receptors in human T cells. RNA from Jurkat T cells or human T lymphocytes stimulated with PMA $(15 \mathrm{ng} / \mathrm{ml})+$ lon $(1 \mu \mathrm{M})$ for the indicated times (hours) was analyzed by RT-PCR to determine $\sigma-1$ and $\sigma-2 / P G R M C 1$ receptors, IL-2 or GAPDH mRNA levels. An aliquot of the amplified DNA was separated on an agarose gel and stained with ethidium bromide for qualitative comparison. 
(5'-GGCCAAAGAGGTAGGTGG-3'); $\sigma$-2/PGRMC1-sense (5'ATCATGGCTGCCGAGGATGTG- ${ }^{\prime}$ ); $\sigma$-2/PGRMC1-antisense ( $5^{\prime}$ GAGGTCAGAAAGGTCATCGTAC- $\left.3^{\prime}\right)$.

GAPDHsense (5'-TGGCAAATTCCATGGCA- ${ }^{\prime}$ ); GAPDHantisense ( $5^{\prime}$-TCTAGACGGCAGGTCAGGTCCACC-3'); IL-2sense (5'-ATGTACAGGATGCAACTCCTGTCTT-3'); IL-2antisense (5' GTCAGTGTTGAGATGATGCTTTGAC- $3^{\prime}$ ).

PCR reaction was amplified by $25-30$ cycles of denaturation at $94^{\circ} \mathrm{C}$ for $45 \mathrm{~s}$, annealing at 55 or $60^{\circ} \mathrm{C}$ for $45 \mathrm{~s}$, and extension at $72^{\circ} \mathrm{C}$ for $45 \mathrm{~s}$. PCR products were separated on agarose gel electrophoresis and visualized by ethidium bromide staining.

For quantitative real-time RT-PCR analysis, total RNA was reversed transcribed using the components of the High Capacity cDNA Archive Kit (Applied Biosystems). Amplification of cDNAs was performed using the TaqMan Universal PCR Master Mix (Applied Biosystems) on an ABI PRISM 7900HT instrument (Applied Biosystems) for 40 cycles with specific primers and Taqman MGB probes for IL-2, TNF $\alpha$, COX-2, and GAPDH. (Applied Biosystems). All samples were run in triplicate. Quantification of gene expression by real-time RT-PCR was calculated by the comparative threshold cycle $(\Delta \Delta \mathrm{CT})$ method following the manufacturer's instructions. Relative quantification (RQ) of mRNA levels was determined using endogenous expression of GAPDH and is shown in all the experiments as $R Q \pm$ standard deviation $(\mathrm{SD})$.

\section{TRANSFECTION AND LUCIFERASE ASSAYS}

Luciferase reporter assays in Jurkat cells were performed by transient transfection of different plasmids in exponential growing cells $\left(1 \times 10^{6}\right.$ cells $/ \mathrm{ml}$ in OPTIMEM medium) by the Lipofectamine 2000 reagent (Invitrogen). After $4 \mathrm{~h}$ of incubation, RPMI medium containing 5\% FBS was added to cells and the incubation was continued for $16 \mathrm{~h}$ to complete transfection. Cells were treated with increasing doses of the indicated compounds for $1 \mathrm{~h}$ prior to treatment with PMA $(15 \mathrm{ng} / \mathrm{ml})+$ Ion $(1 \mu \mathrm{M})$ for additional $5 \mathrm{~h}$. Luciferase activity was determined in cell lysates with a luciferase assay kit (Promega) with a luminometer Monolight 2010 (Analytical Luminescence Laboratory). Results are represented as percentage of activity, considering $100 \%$ that obtained in the PMA + Ion stimulated samples, and are shown as the mean \pm SD from triplicate assays.

Human COX-2 promoter construct COX-2-Luc (p2-1900) has been described previously (Iniguez et al., 1999). The IL-2-LUC plasmid contains the region spanning from -326 to +145 of the human IL-2 promoter (Durand et al., 1988). The plasmid $\mathrm{TNF} \alpha$-LUC contains a region $1311 \mathrm{bp}$ upstream from the transcriptional initiation site of human $\mathrm{TNF} \alpha$ promoter (Rhoades et al., 1992). The NFAT-LUC reporter construct contains three tandem copies of the distal NFAT binding site fused to the IL-2 minimal promoter (Durand et al., 1987). NF- $\kappa B$ luciferase reporter contains three tandem repeats of the NF- $\mathrm{B}$-binding site from the
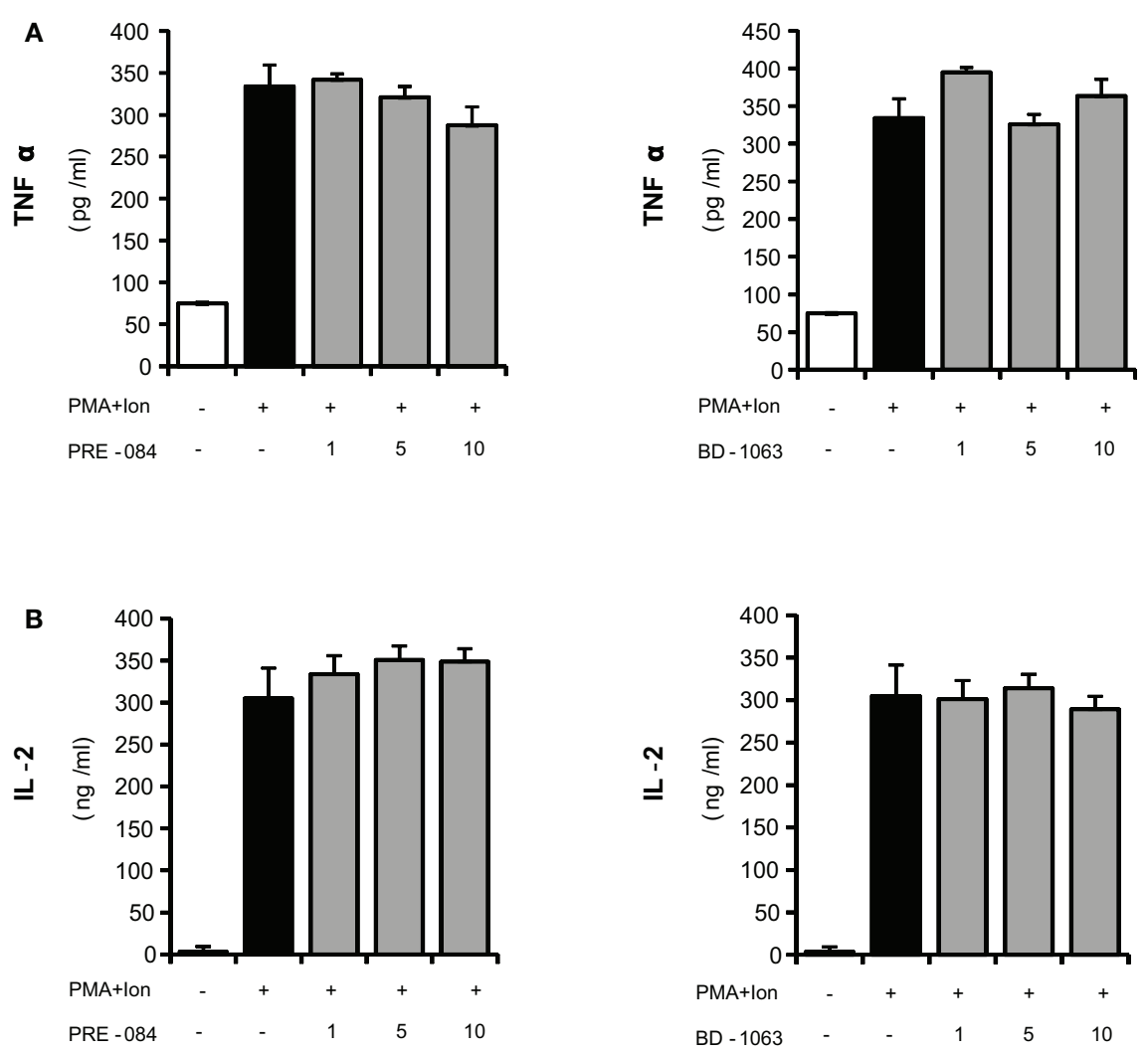

FIGURE 2 | Effects of $\sigma-1$ ligands on TNF $\alpha$ and IL-2 production by activated Jurkat $T$ cells. Jurkat cells were treated for $16 \mathrm{~h}$ with PMA $(15 \mathrm{ng} / \mathrm{ml})+$ lon $(1 \mu \mathrm{M})$ in the presence of different concentrations $(1,5$,

and $10 \mu \mathrm{M})$ of the $\sigma-1$ agonist PRE-O84 or the antagonist BD-1063. Levels of TNF $\alpha$ (A) and IL-2 (B) released into the medium were measured by an ELISA assay. 
Igא promoter located upstream of a minimal conalbumin promoter controlling the luciferase gene (Arenzana-Seisdedos et al., 1993).

\section{CYTOKINE MEASUREMENT}

The concentration of IL-2 and TNF $\alpha$ in supernatants of Jurkat cell cultures was determined using specific ELISAs in the presence or absence of $\sigma$ ligands. Commercially available kits were used according to manufacturer's instructions (Bender MedSystems). Cytokine concentration was assayed in triplicate.

\section{PROSTAGLANDIN E 2 MEASUREMENT}

To evaluate $\mathrm{PGE}_{2}$ production in Jurkat cells after the different treatments, the media was aspirated and cells rinsed with $\mathrm{HBS}, \mathrm{pH}$ 7.4 , supplemented with $0.1 \%$ BSA. Then, cells were incubated for $30 \mathrm{~min}$ at $37^{\circ} \mathrm{C}$ in the same buffer with an excess of AA $(10 \mu \mathrm{M})$. Levels of $\mathrm{PGE}_{2}$ were determined in the supernatants using a $\mathrm{PGE}_{2}$ enzyme immunoassay kit (Cayman Chemical). All samples were tested in triplicate.

\section{IMMUNOBLOT ANALYSIS}

Total extracts of Jurkat cells were obtained after lysis for $30 \mathrm{~min}$ in ice-cold lysis buffer (Phosphate-buffered saline, 1\% Non-idet P-40, 0.5\% sodium deoxycholate, $0.1 \%$ SDS, $1 \mathrm{mM}$ phenylmethylsulphonyl fluoride, $2 \mu \mathrm{g} / \mathrm{ml}$ aprotinin, $2 \mu \mathrm{g} / \mathrm{ml}$ leupeptin, and $1 \mu \mathrm{g} / \mathrm{ml}$ pepstatin, $1 \mathrm{mM}$ sodium orthovanadate and $1 \mathrm{mM}$ sodium fluoride). Lysates were denatured and resolved by SDS-polyacrylamide gel electrophoresis and then transferred to nitrocellulose membranes. The filters were incubated with anti-NFAT antisera (anti-NFATc2 \#672; 1:3000; generous gift of Dr. J. M. Redondo) that recognize both the dephosphorylated and phosphorylated forms of NFAT (San-Antonio et al., 2002; Jimenez et al., 2004). $\beta$-actin levels were determined as a control of loading in each lane with a specific antibody (Santa Cruz Biotechnology). After incubation with a goat antirabbit IgG secondary antibody linked to horseradish peroxidase (Pierce) at 1:15000 dilution, the stained bands were visualized with the ECL (enhanced chemiluminescence) detection reagent (Pierce).

\section{STATISTICS}

Results are expressed as mean \pm SD from at least three independent experiments performed by duplicate or triplicate. Statistical analysis was carried out by the Student $t$-test with $p<0.05$ representing significance. Statistical analyses were done using Graph Pad software.

\section{RESULTS}

\section{EXPRESSION OF THE $\sigma$ RECEPTORS IN HUMAN T LYMPHOCYTES}

Expression of the $\sigma-1$ and $\sigma-2 /$ PGRMC1 receptors mRNAs in human T cells was analyzed by RT-PCR. As shown in Figure 1, constitutive expression of the $\sigma-1$ and $\sigma-2 /$ PGRMC1 receptors mRNAs were detected in Jurkat $\mathrm{T}$ cell line and in primary lymphocytes isolated from human blood. Expression of these receptors did not seem to be influenced by activation of the cells with the phorbol ester PMA + the $\mathrm{Ca}^{++}$ionophore A23187 (Ion) at any of the times
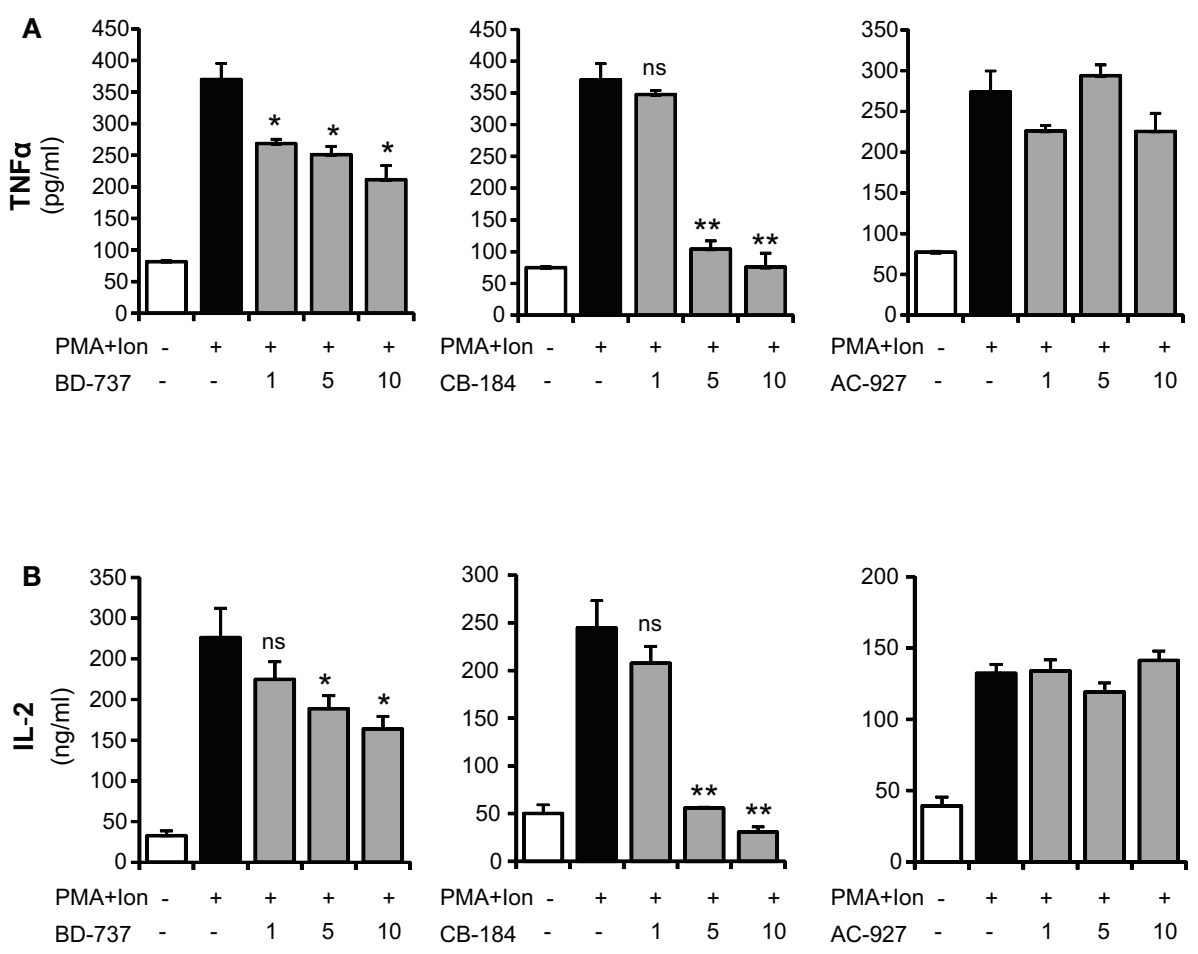

FIGURE 3 | Inhibition of TNF $\alpha$ and IL-2 production by $\sigma-2$ agonists in activated Jurkat $T$ cells. Jurkat cells were treated for $16 \mathrm{~h}$ with PMA $(15 \mathrm{ng} / \mathrm{ml})+$ lon $(1 \mu \mathrm{M})$ in the presence of different concentrations $(1,5$, and
$10 \mu \mathrm{M})$ of the $\sigma-2$ agonists BD-737 and CB-184 or the antagonist AC-927. Levels of TNF $\alpha$ (A) and IL-2 (B) released into the medium were measured by an ELISA assay. (n.s, not significant; ${ }^{*} p<0.05 ;{ }^{*} p<0.01$ versus PMA + Ion). 
analyzed. This pharmacologic treatment is known to mimic T cell receptor activation (TCR) in T cells. IL-2 mRNA expression was induced in a time-course dependent manner, which serves as a control of gene transcriptional induction upon T lymphocyte activation. Levels of GAPDH mRNA are shown as a control of loading. These results indicate that both $\sigma-1$ and $\sigma-2 / \mathrm{PGRMC1}$ receptors
A
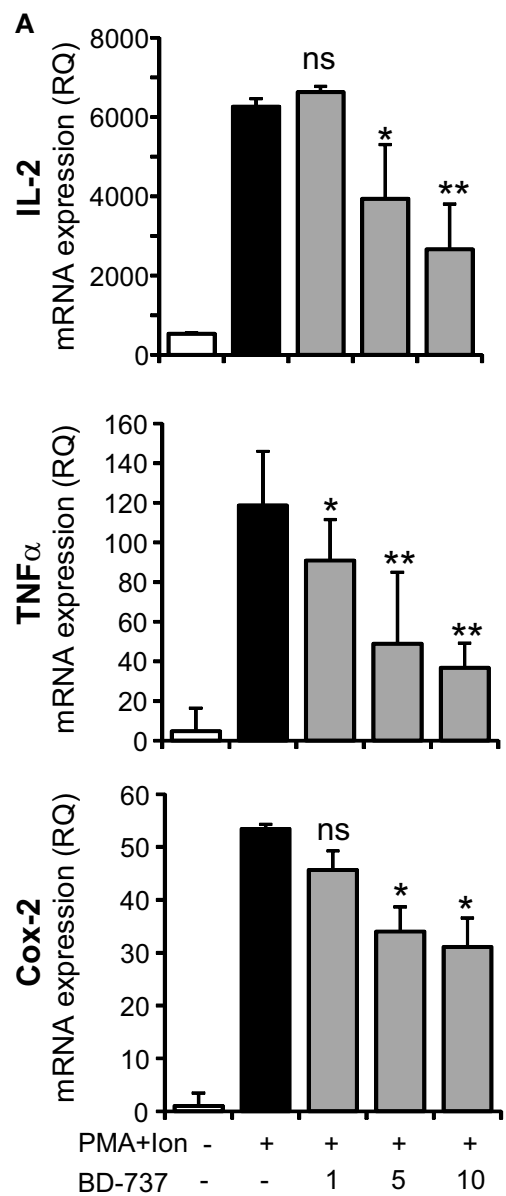
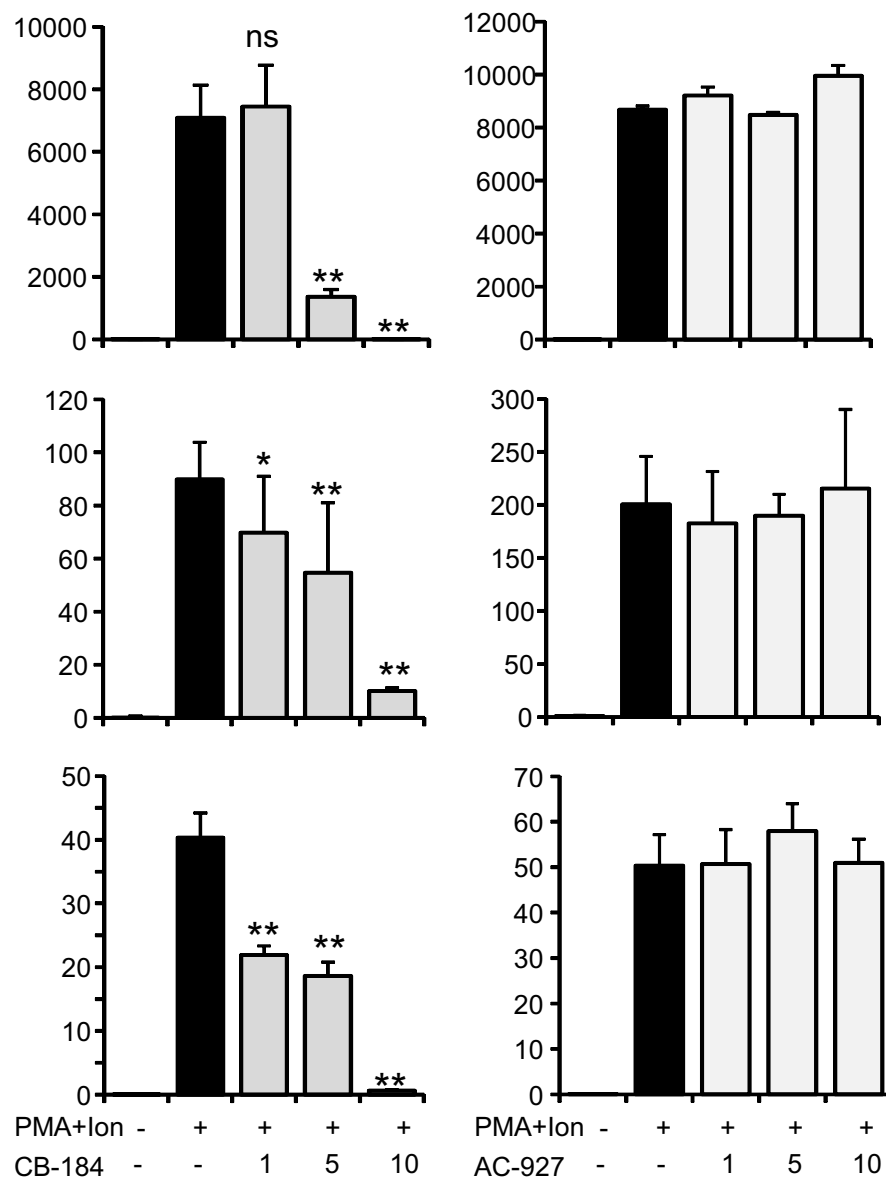
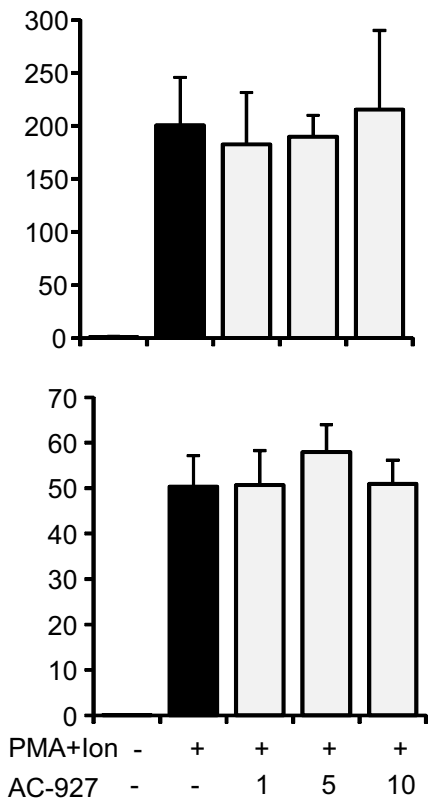

B

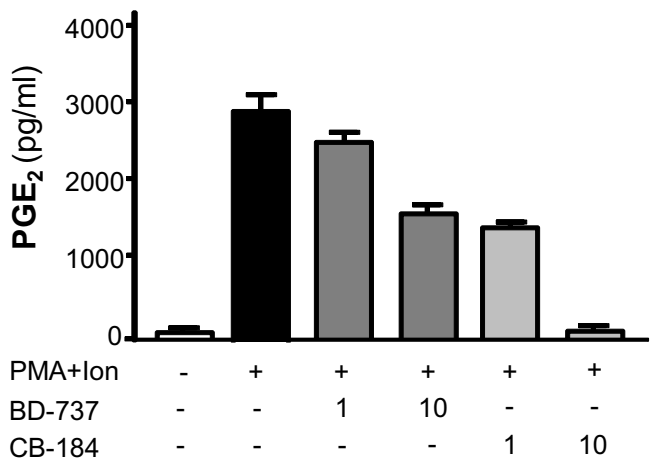

FIGURE 4 | Effect of $\sigma-2$ ligands on the expression of IL-2, TNF $\alpha$, and COX-2 in Jurkat T cells. (A) Total RNA from Jurkat cells, treated with $\sigma-2$ agonists BD-737 and CB-184 or the antagonist AC-927 at the doses indicated $(1,5$, and $10 \mu \mathrm{M})$ and grown in the absence or presence of PMA $(15 \mathrm{ng} / \mathrm{ml})+$ lon $(1 \mu \mathrm{M})$, was analyzed by quantitative RT-PCR. Relative quantification (RQ) of mRNA levels of IL-2, TNF $\alpha$, and COX-2 was determined using endogenous expression of GAPDH and is shown as $R Q \pm S D$. (B) $P G E_{2}$ production by Jurkat cells treated with $\sigma-2$ agonists BD-737 and CB-184 at the doses indicated ( 1 and $10 \mu \mathrm{M}$ ), grown in the absence or presence of $\mathrm{PMA}+$ Ion. $\mathrm{PGE}_{2}$ was measured by a standard EIA assay as described in Section "Materials and Methods." Results are shown as the mean $\pm \mathrm{SD}$ of $\mathrm{PGE}_{2}$ in $\mathrm{pg} / \mathrm{ml}$ of determinations conducted in triplicate. (n.s, not significant; ${ }^{*} p<0.05$; ${ }^{*} p<0.01$ versus PMA + Ion). 

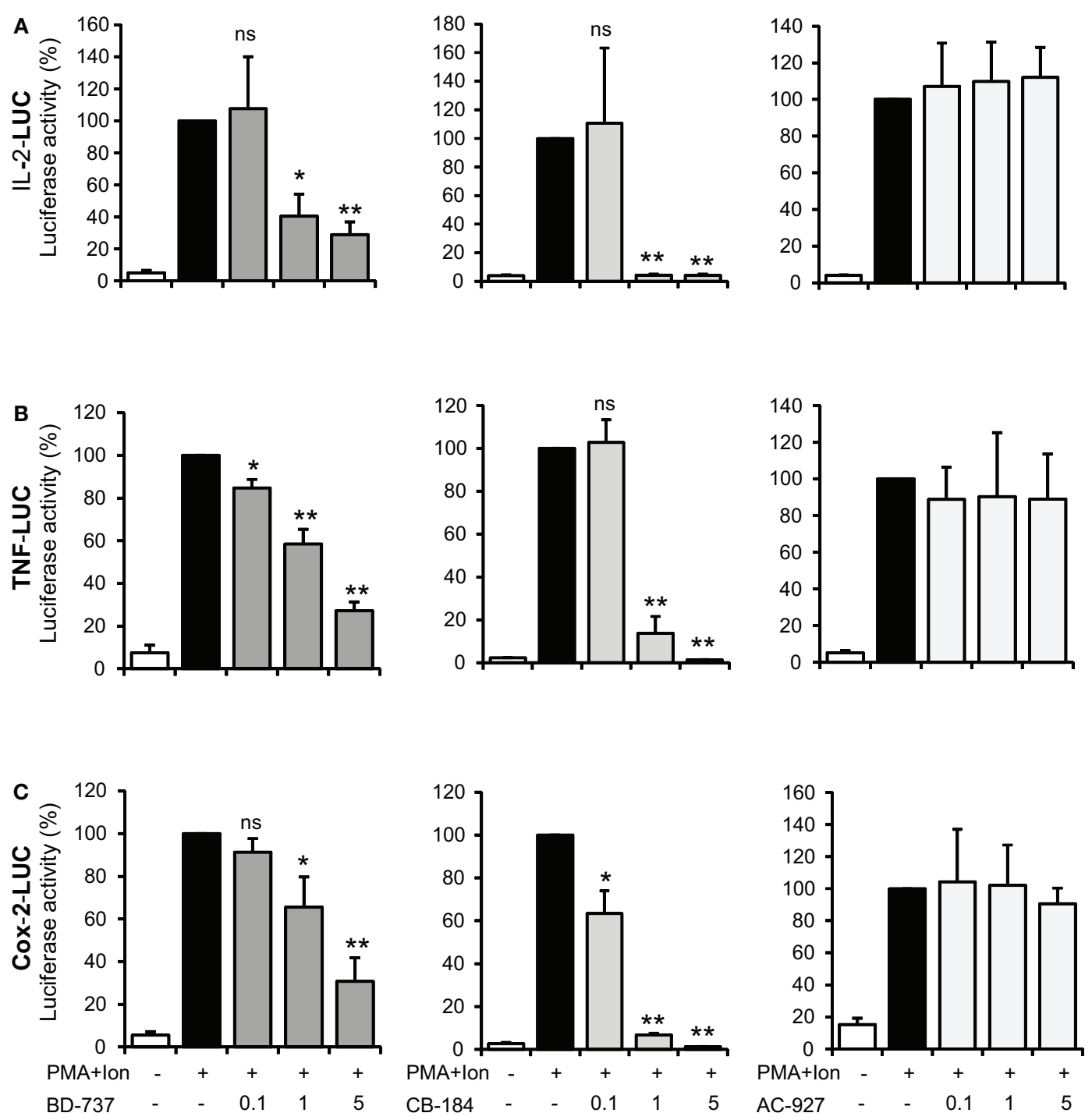

FIGURE 5 | Inhibitory effect of $\sigma-2$ agonists on the activity of IL-2, TNF $\alpha$, and COX-2 promoters in Jurkat T cells. Jurkat cells were transiently transfected with luciferase reporter constructs containing the promoter regions of the IL-2 (A), TNF $\alpha$ (B), or COX-2 (C) genes and treated for $6 \mathrm{~h}$ with PMA $(15 \mathrm{ng} / \mathrm{ml})+$ lon $(1 \mu \mathrm{M})$ in the absence or presence of increasing doses
$(0.1,1$, and $5 \mu \mathrm{M})$ of $\sigma-2$ ligands BD-737 and CB-184 ( $\sigma-2$ agonists) or AC-927 $(\sigma-2$ antagonist) as indicated. Luciferase activity was measured and represented in percentage of activity considering $100 \%$ the activity obtained upon PMA + lon stimulation in the absence of $\sigma$ ligand. (n.s, not significant; ${ }^{*} p<0.05 ;{ }^{*} p<0.01$ versus PMA + lon). are constitutively expressed in human T lymphocytes but they are not modulated by TCR activation.

\section{EFFECT OF $\sigma$-1 AND $\sigma-2$ LIGANDS ON CYTOKINE PRODUCTION IN T CELLS}

Activated $\mathrm{T}$ cells produce a variety of cytokines such as IL-2 and TNF- $\alpha$, among others. The coordinated production of these cytokines is crucial for regulation of the inflammatory response. We evaluated the immunomodulatory actions of increasing doses of $\sigma$ ligands on the production of IL- 2 and TNF $\alpha$ by activated Jurkat cells. Both selective $\sigma-1$ agonist PRE-084 ( $K_{\mathrm{i}}$ values of 2.2 and $13091 \mathrm{nM}$ for $\sigma-1$ and $\sigma-2$ receptors respectively; Su et al., 1991; Rossi et al., 2011) and $\sigma-1$ antagonist BD-1063 ( $K_{\mathrm{i}}$ value of
$9 \mathrm{nM}$ for the $\sigma-1$ receptor and more than 49 times selectivity over the $\sigma-2$ receptor; Matsumoto et al., 1995; Entrena et al., 2009), were used to determine the effect of $\sigma-1$ ligands in these cells. As shown in Figure 2, neither the $\sigma-1$ agonist PRE-084 nor the $\sigma-1$ antagonist BD-1063 showed a significant effect on the induction of the production of IL- 2 or TNF $\alpha$ in Jurkat T cells upon stimulation with PMA + Ion.

We next evaluated the effects of different $\sigma-2$ ligands in these cells: CB-184, described as a selective $\sigma-2$ receptor agonist with 554-fold selectivity for $\sigma-2$ receptors over $\sigma-1$ (Bowen et al., 1995; Vilner and Bowen, 2000; Crawford et al., 2002); BD-737, a potent $\sigma$ receptor ligand with properties as $\sigma-2$ ligand (Bowen et al., 1992; Vilner and Bowen, 2000; Crawford et al., 2002); and the 
б-2 receptor antagonist AC927 (Crawford et al., 2002; Berardi et al., 2004; Matsumoto et al., 2008). Different to $\sigma-1$ ligand, both $\sigma-2$ agonists, BD-737, and CB-184, produced a dose-dependent decrease in the PMA + Ion-mediated induction of IL- 2 or TNF $\alpha$ production, with the strongest effect observed after treatment with CB-184. The $\sigma-2$ antagonist AC-927 did not show a significant effect at any of the doses assayed (Figure 3 ).

To determine whether the effects of sigma ligands on cytokine production were a consequence of changes in mRNA expression, we performed quantitative real-time RT-PCR assays, analyzing mRNA levels of these cytokines as well as of another gene involved in inflammation as cyclooxygenase (COX)-2. In agreement to the above results, increasing doses of $\sigma-2$ agonists significantly diminished the induction by PMA + Ion of TNF $\alpha$, IL-2, or COX-2 mRNAs (Figure 4A). No effect of the $\sigma-2$ antagonist AC-927 was observed. The inhibitory effects of these $\sigma-2$ agonists on COX2 expression correlated with those observed with COX activity. Thus, BD-737 and CB-184 produced a dose-dependent decrease in the $\mathrm{PMA}+$ Ion-mediated induction of $\mathrm{PGE}_{2}$ production in Jurkat cells (Figure 4B).

Changes in mRNA levels can take place by the influence of these ligands on transcriptional induction, so we next investigated the regulation of $\mathrm{TNF} \alpha, \mathrm{IL}-2$, and COX-2 promoters in Jurkat cells. As shown in Figure 5, treatment with PMA + Ion induced a substantial increase in the transcriptional induction mediated by these promoters in Jurkat T cells. Treatment with $\sigma-2$ agonists, BD-737,
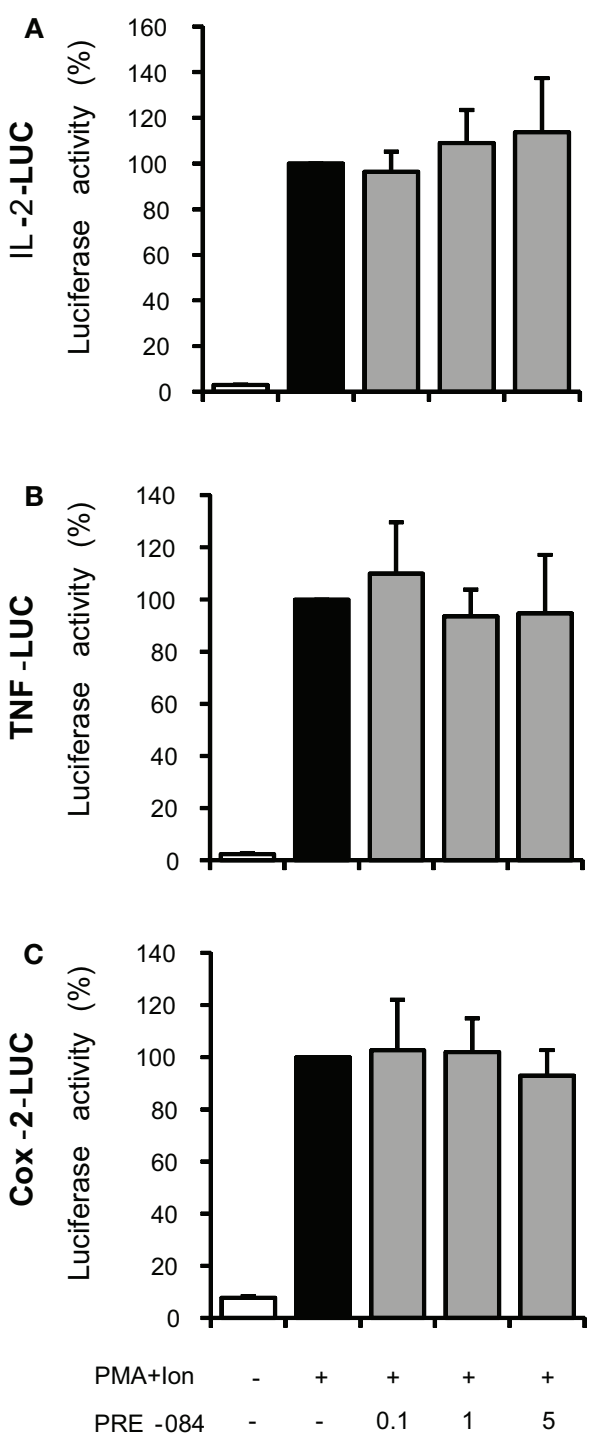

FIGURE 6 | Effect of $\sigma-1$ ligands on the activity of IL-2, TNF $\alpha$, and COX-2 promoters in Jurkat T cells. Jurkat cells were transiently transfected with luciferase reporter constructs containing the promoter regions of the IL-2 (A), TNF $\alpha$ (B), or COX-2 (C) genes and treated for $6 \mathrm{~h}$ with PMA $(15 \mathrm{ng} / \mathrm{ml})+$ lon $(1 \mu \mathrm{M})$ in the absence or
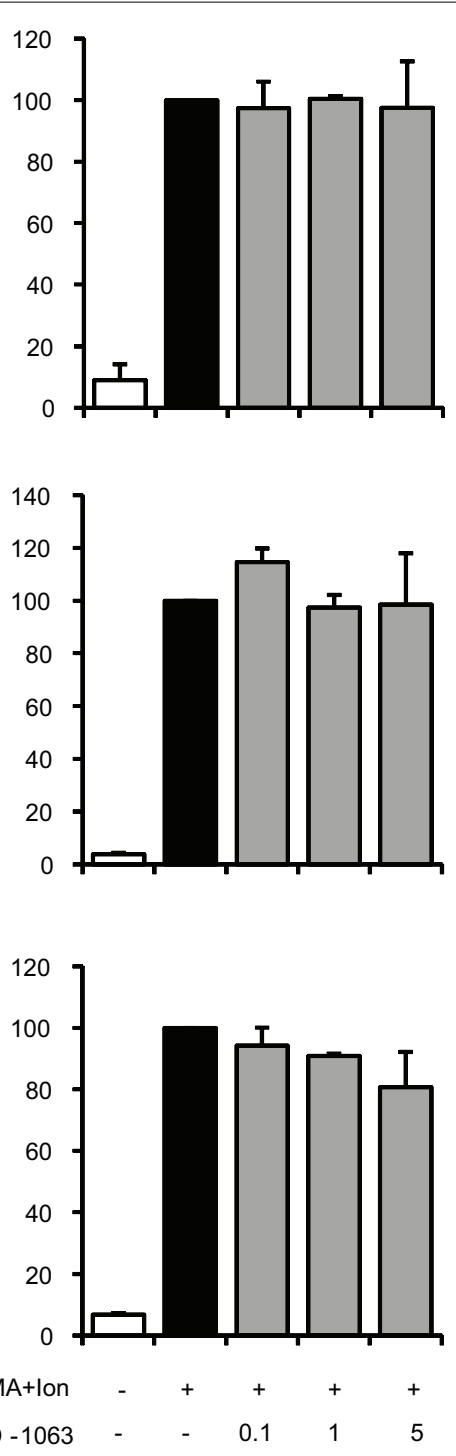

presence of increasing doses $(0.1,1$, and $5 \mu \mathrm{M})$ of the $\sigma-1$ agonist PRE-084 or $\sigma-1$ antagonist BD-1063 as indicated. Luciferase activity was measured and represented in percentage of activity considering $100 \%$ the activity obtained upon PMA + Ion stimulation in the absence of $\sigma$ ligand. 
and CB-184, but not with the $\sigma-2$ antagonist AC-927, was able to severely impair transcriptional activation mediated by PMA + Ion in Jurkat T cells. Again, no changes in the activity of these promoters upon PMA + Ion were observed by treatment with $\sigma-1$ ligands (Figure 6).

\section{EFFECTS OF $\sigma-1$ AND $\sigma-2$ LIGANDS ON NF- $\kappa$ B AND NFAT-DEPENDENT TRANSCRIPTIONAL ACTIVATION IN T CELLS}

Transcriptional activation of a variety of genes induced upon $\mathrm{T}$ cell activation, including TNF- $\alpha$, IL-2, and COX-2, depends on the coordinate interactions among several transcription factors, including members of NF- $\mathrm{B}$, and NFAT families (Rao et al.,
1997; Crabtree, 1999). To determine whether inhibition of gene expression was occurring through the action of $\sigma$ ligands on the activation of these transcription factors, we evaluated the effect of these compounds on the activity of NF- $\mathrm{B}$ and NFAT by using luciferase reporter gene constructs including minimal promoters under the control of NFAT or NF- $\kappa$ B-binding sites. Treatment with $\mathrm{PMA}+$ Ion promoted an important increase in the activity of both NF- $\mathrm{B}-L U C$ and NFAT-LUC reporter constructs in Jurkat T cells. Figures 7A,B shows the results obtained with the $\sigma-2$ agonists BD-737 and CB-184 and $\sigma-2$ antagonist AC-927. Sigma-2 agonists treatment displayed a profound inhibitory effect on transcriptional activation mediated by both NF- $\mathrm{B}$ and NFAT. In contrast,

A
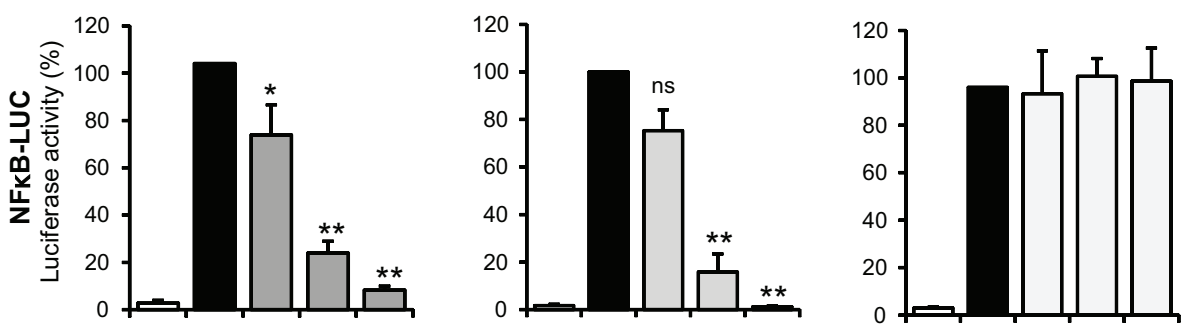

B
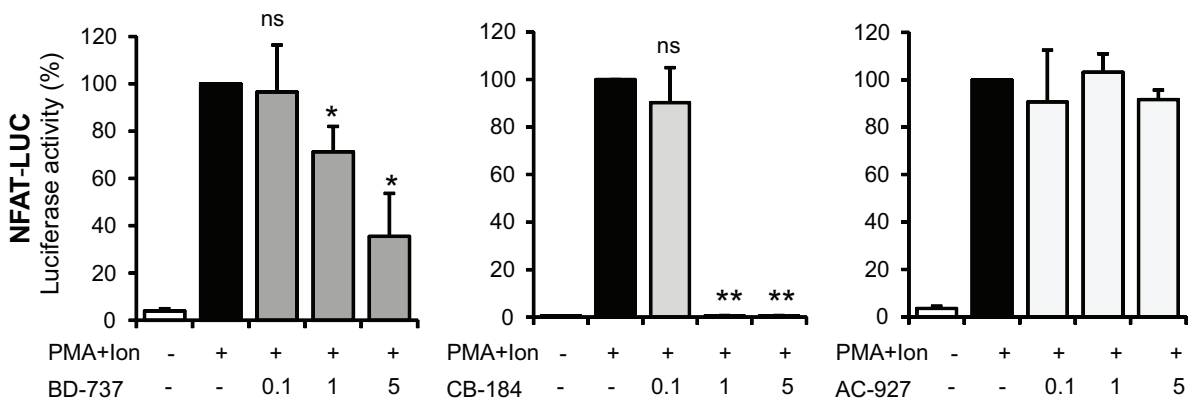

C
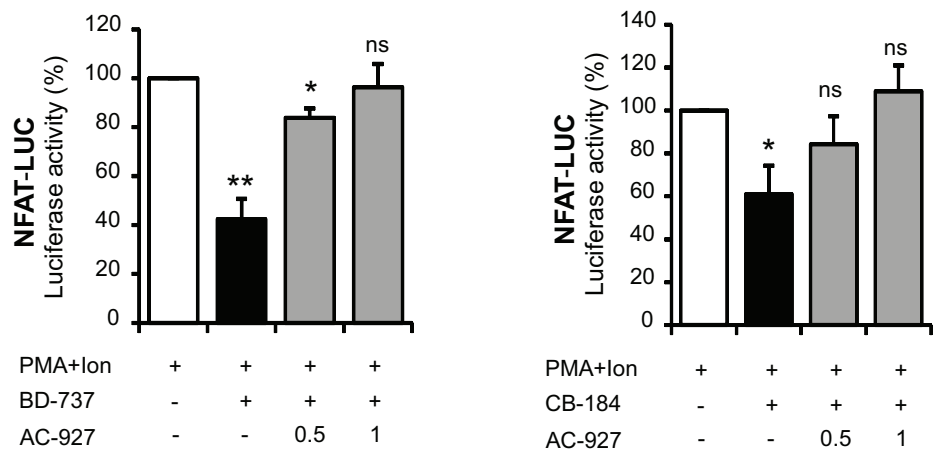

FIGURE 7 | Effect of $\sigma-2$ ligands on transcriptional induction mediated by NF-KB and NFAT in Jurkat T cells. Jurkat cells were transiently transfected with the luciferase reporter constructs NF-KB-LUC (A) or NFAT-LUC (B) and treated for $6 \mathrm{~h}$ with PMA $(15 \mathrm{ng} / \mathrm{ml})+$ lon $(1 \mu \mathrm{M})$ in the absence or presence of increasing doses $(0.1,1$, and $5 \mu \mathrm{M})$ of $\sigma-2$ agonists (BD-737 and CB-184) or antagonist (AC-927). (C) Cells transfected with the NFAT-LUC plasmid and treated with PMA + lon were treated with $\sigma-2$ agonists BD-737 $(5 \mu \mathrm{M})$ or CB-184 $(0.5 \mu \mathrm{M})$ in the absence or presence of increasing doses of $\sigma-2$ antagonist AC-927 $(0.5$ and $1 \mu \mathrm{M})$. Luciferase activity was measured and represented in percentage of activity considering $100 \%$ the activity obtained upon PMA + lon stimulation in the absence of $\sigma$ ligands. (n.s, not significant; ${ }^{*} p<0.05 ;{ }^{*} p<0.01$ versus PMA + Ion). 
б-2 antagonist AC927 or $\sigma-1$ ligands PRE-084 and BD-106 did not exhibit any significant effect on the activity of these transcription factors (Figures 7 and 8 ).

Inhibitors of NFAT activation as Cyclosporine A or Tacrolimus are well-known immunomodulatory drugs with a potent immunosuppressive effect (Kiani et al., 2000; Martinez-Martinez and Redondo, 2004). The above results pointed to $\sigma-2$ agonists as able to interfere with NFAT-dependent transcriptional activation of gene expression. To further confirm the specificity of the actions of $\sigma-2$ agonists on NFAT activation, we tested whether a $\sigma-2$ antagonist could block this effect. As shown in Figure 7C, the inhibitory effect of both BD-737 and CB-184 on NFAT-LUC was reversed in a dose-response manner by the $\sigma-2$ antagonist AC927. To address the mechanism involved in the actions of these compounds on NFAT-dependent transcription, we next analyzed the effect of these compounds on NFAT phosphorylation. In resting $\mathrm{T}$ cells, NFAT is a cytoplasmic factor that upon activation is dephosphorylated by the calcineurin phosphatase and translocated into the nucleus leading to transactivation of target genes (Rao et al., 1997; Crabtree, 1999; Hogan et al., 2003). As shown in Figure 9, upon activation with PMA + Ion NFAT is dephosphorylated, showing a decrease in phosphorylated NFAT signal and an increase in a band of dephosphorylated NFAT, which migrates faster in SDS-PAGE. Both BD-737 and CB-184 partially inhibited in a dose-dependent manner the dephosphorylation of NFAT. In contrast, AC 927 had no effect. As a control it is shown the inhibition of calcineurin phosphatase activity by Cyclosporin A (CsA) and hence, NFAT dephosphorylation, which is known to result in a complete prevention of nuclear translocation of NFAT (Kiani et al., 2000; Martinez-Martinez and Redondo, 2004). This result pointed to $\sigma-2$ agonists as inhibitor of NFAT signaling, interfering with the early steps in the activation of this factor.

Taken together, our results support an inhibitory role of NFATmediated transcriptional activation in Jurkat T cells by the $\sigma-2$ agonists BD-7373 and CB-184, which, in addition to inhibition of $\mathrm{NF}-\kappa \mathrm{B}$ activation, could account for the inhibitory actions on the transcriptional induction and expression of activation-induced genes such as $\mathrm{TNF} \alpha, \mathrm{IL}-2$, and COX-2.

\section{DISCUSSION}

In this report we have analyzed the effect of $\sigma$ ligands on $\mathrm{T}$ cell function. Our results show a novel pharmacological activity of sigma-2 ligands on the immune system. Namely, $\sigma-2$ agonists have immunosuppressive activity in T lymphocytes. On the other
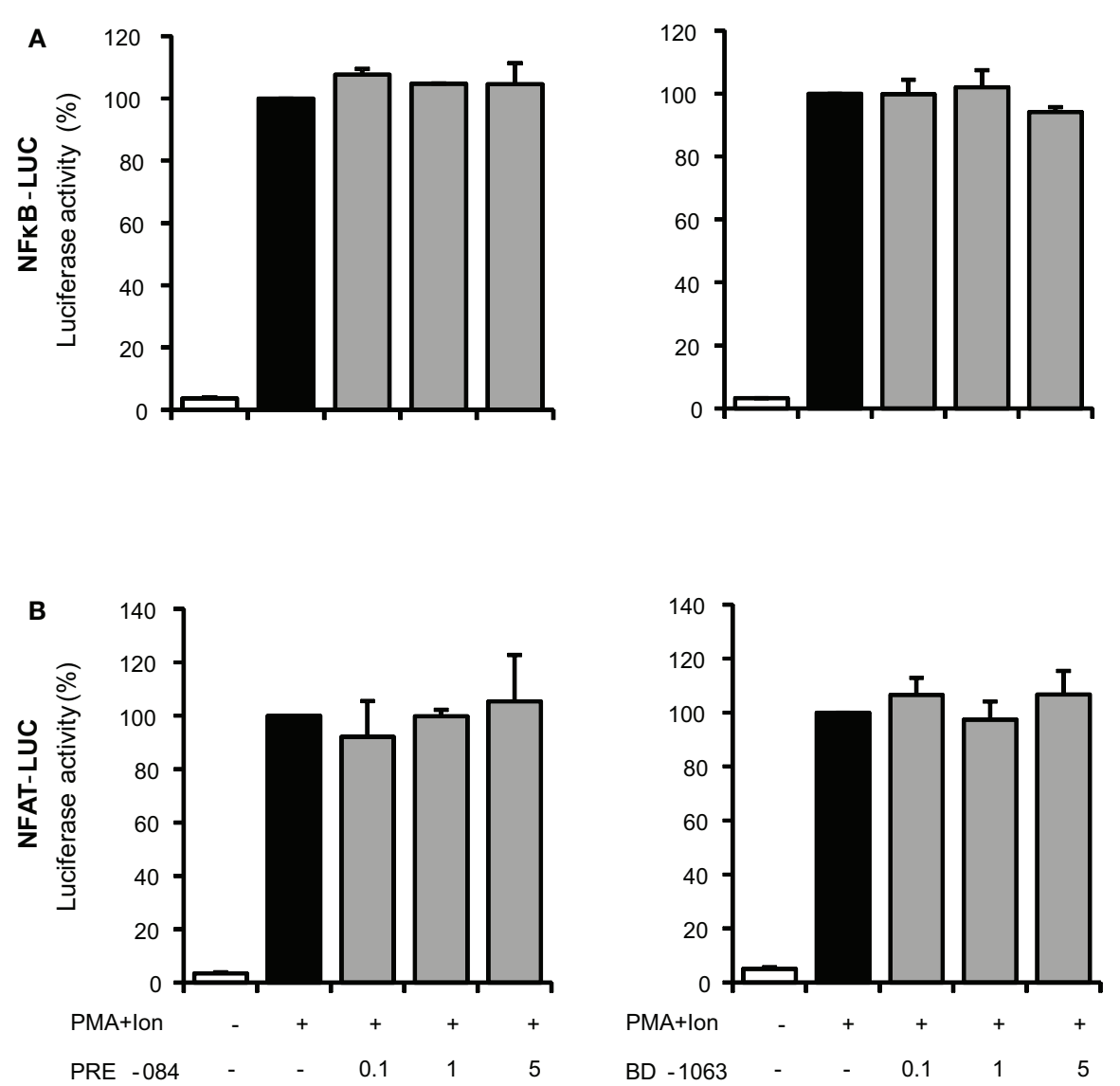

FIGURE 8 | Effect of $\sigma-1$ ligands on transcriptional induction mediated by NF-кB and NFAT in Jurkat T cells. Jurkat cells were transiently transfected with the luciferase reporter constructs NF-KB-LUC (A) or NFAT-LUC (B) and treated for $6 \mathrm{~h}$ with PMA $(15 \mathrm{ng} / \mathrm{ml})+\operatorname{lon}(1 \mu \mathrm{M})$ in the absence or presence of increasing doses $(0.1,1$, and $5 \mu \mathrm{M})$ of the $\sigma-1$ agonist (PRE-084 and CB-184) or antagonist (AC-927). Luciferase activity was measured and represented in percentage of activity considering $100 \%$ the activity obtained upon PMA + lon stimulation in the absence of $\sigma$ ligands. 


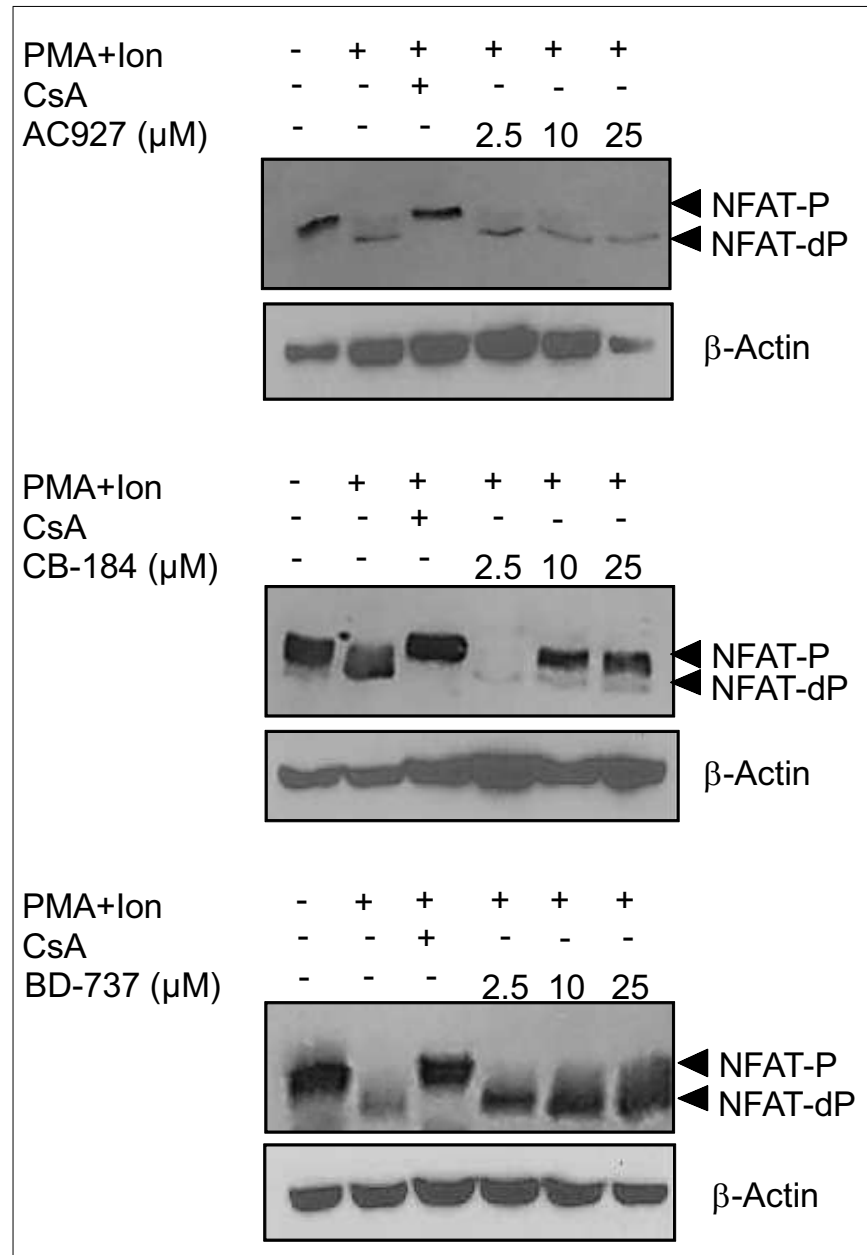

FIGURE 9 | Actions of $\boldsymbol{\sigma} 2$ ligands on NFAT dephosphorylation. Protein extracts from Jurkat treated with PMA $(15 \mathrm{ng} / \mathrm{ml})+$ lon $(1 \mu \mathrm{M})$ for $2 \mathrm{~h}$ in the presence or absence of increasing doses $(2.5,10$, and $25 \mu \mathrm{M})$ of $\sigma-2$ agonists (BD-737 and CB-184) or antagonist (AC-927) were analyzed by Western blot with an anti-NFAT serum. The phosphorylated (NFAT-P) and dephosphorylated (NFAT-dP) forms of NFATc2 are indicated by arrows. Inhibition of NFAT dephosphorylation by Cyclosporin A (CsA) is shown as a control. $\beta$-Actin protein levels were determined as a control of loading.

hand, signaling through the $\sigma-1$ receptor, at least by the results obtained with the selected $\sigma-1$ agonists or antagonists, does not seem to exert evident functional consequences on the immune activation parameters assayed. We found that basal levels of $\sigma$ 1 receptor mRNA are present in resting human $\mathrm{T}$ cells that do not change upon $\mathrm{T}$ cell activation. A similar profile of expression was observed with the recently described putative $\sigma-2$ receptor PGRMC1 (Xu et al., 2011). Expression of this receptor has been described in peripheral blood cells and T lymphocytes, being elevated in multiple tumor types (Mir et al., 2012; Ndiaye et al., 2012). The existence of a $\sigma$ binding site in the Jurkat human $\mathrm{T}$ cell line corresponding to an alternatively spliced $\sigma-1$ receptor variant has been previously described (Ganapathy et al., 1999). Nonetheless, pharmacology of the sigma binding site in Jurkat T cells seems to be consistent with the $\sigma-2$ receptor subtype (DeHaven-Hudkins et al., 1996).
Several reports have described anti-inflammatory and immunoregulatory properties of $\sigma$ ligands both "in vitro" and “in vivo" (Casellas et al., 1994; Bourrie et al., 1995, 2002; Carayon et al., 1995; Derocq et al., 1995; Liu et al., 1995; Gannon et al., 2001; Zhu et al., 2003). However the exact biological significance and the nature of $\sigma$ receptor signaling mediating these effects are poorly understood. Several of the anti-inflammatory and immunosuppressive effects of sigma ligands in immune cells have been suggested to be indirect, due to their ability of these compounds to induce anti-inflammatory cytokines as TGF $\beta$ or IL-10 (Bourrie et al., 1995; Zhu et al., 2003; Kvaratskhelia et al., 2009) or even by promoting glucocorticoid-dependent immunosuppression (Derocq et al., 1995). Moreover, controversial data about the identification of these effects as selectively dependent on $\sigma-1$ or $\sigma-2$ exist. There is a lack of consistency between pharmacology of $\sigma$ binding selectivity and the immunomodulatory events observed in response to $\sigma$ ligands. These discrepancies may be due to the different $\sigma$ compounds used or to the fine specificity of those ligands for different unidentified target receptors in immune cells. Kvaratskhelia et al. (2009) have reported that $\sigma$ ligands can modulate IL- 8 and IL- 10 production by T cells through modulation of the NMDA Glutamate Receptor. Particularly, very little is known about the pharmacology of $\sigma-2$ receptors and the effect of ligands acting specifically through this receptor. The fact that the real nature of the $\sigma-2$ receptor has not been clearly determined has prevented further analysis. Signaling cascades directly coupled to activation of this receptor have not yet been identified and only some data is available on its function.

Here we provide some new data on $\sigma-2$ receptor function and signaling. Thus, we have found that the $\sigma-2$ receptor agonists $\mathrm{BD}$ 737 and CB-184 had an interesting behavior compatible with being immunosuppressive and anti-inflammatory drugs. Since our results show that two $\sigma-2$ receptor agonists with different chemicals properties have a similar effect which is reversed by a $\sigma-2$ antagonist, it is likely that a putative $\sigma-2$ receptor binding site participates in the observed effect in T lymphocytes. In contrast to $\sigma-1$ compounds, here, we have shown that $\sigma-2$ agonists but not just a merely $\sigma-2$ ligand as the $\sigma-2$ antagonist AC927 are able to decrease $\mathrm{T}$ cell activation "in vitro". Those two $\sigma-2$ agonist compounds of different chemical structure inhibited COX-2, TNF $\alpha$, and IL-2 mRNA as well as cytokine release by activated $\mathrm{T}$ cells. Those effects seem to occur through inhibition of transcriptional activation of these genes as $\sigma-2$ agonists were able to diminish the PMA + Ion-mediated induction of the activity of $\mathrm{TNF} \alpha, \mathrm{IL}-2$, and COX-2 promoters in T cells. This effect takes place at the transcriptional level, reducing NFAT and NF- $\kappa \mathrm{B}$ activation. We present evidence showing that BD-737 and CB-184 inhibited PMA + Ion-mediated activation of NFAT, altering its dephosphorylation and hence nuclear shuttling and NFAT-mediated gene transcription. Interestingly, the effects on NFAT-dependent transcription can be prevented by a $\sigma-2$ antagonist, further confirming the specificity of action. NFAT proteins play an important role in many cellular processes being involved in the regulation of the expression of a variety of T cell cytokines (IL-2, IL-4, IL-5, IL-6, IL-8, IL-13, IFN- $\gamma$, TNF- $\alpha$ ) essential for the immune response and inflammation (Rao et al., 1997; Crabtree, 1999; Hogan et al., 2003). Thus, inhibition of NFAT activation by $\sigma-2$ agonist may explain 
their effects on transcriptional regulation of NFAT-dependent genes. Furthermore, our results show that the $\sigma-2$ agonists evaluated inhibited NFAT dephosphorylation, an essential step for NFAT activation and entry into the nucleus (Rao et al., 1997; Crabtree, 1999; Hogan et al., 2003). Treatment with increasing doses of $\sigma-2$ agonist causes NFAT to be maintained in a phosphorylated state and hence block the nuclear translocation of NFAT and, thus NFAT-dependent gene transcription. Whether this effect is occurring by a mechanism involving interference on $\mathrm{Ca}^{++}$signaling or calcineurin phosphatase activity as in the case of the well-known NFAT inhibitors CsA and Tacrolimus (Kiani et al., 2000; MartinezMartinez and Redondo, 2004), remains to be elucidated. Besides, NFAT activation plays a promoting role in cancer (Duque et al., 2005; Viola et al., 2005; Gachet and Ghysdael, 2009). Thus, it is tempting to speculate that some of the effects of $\sigma-2$ agonists on cancer may take place though NFAT inhibition. Further studies are needed to elucidate this hypothesis.

In summary, our results show that $\sigma-2$ agonist-ligands have an important immunosuppresor and anti-inflammatory effect inhibiting $\mathrm{T}$ cell activation at relevant pharmacological doses by blocking transcriptional activation through their interference with

\section{REFERENCES}

Altman, A., Coggeshall, K. M., and Mustelin, T. (1990). Molecular events mediating $\mathrm{T}$ cell activation. Adv. Immunol. 48, 227-360.

Arenzana-Seisdedos, F., Fernandez, B., Dominguez, I., Jacque, J. M., Thomas, D., Diaz-Meco, M. T., et al. (1993). Phosphatidylcholine hydrolysis activates NF-kappa B and increases human immunodeficiency virus replication in human monocytes and T lymphocytes. J. Virol. 67, 6596-6604.

Berardi, F., Ferorelli, S., Abate, C., Colabufo, N. A., Contino, M., Perrone, R., et al. (2004). 4-(tetralin-1-yl)- and 4-(naphthalen-1-yl)alkyl derivatives of 1-cyclohexylpiperazine as sigma receptor ligands with agonist sigma2 activity. J. Med. Chem. 47, 2308-2317.

Bourrie, B., Benoit, J. M., Derocq, J. M., Esclangon, M., Thomas, C., Le Fur, G., et al. (1996). A sigma ligand, SR 31747A, potently modulates Staphylococcal enterotoxin B-induced cytokine production in mice. Immunology 88, 389-393.

Bourrie, B., Bouaboula, M., Benoit, J. M., Derocq, J. M., Esclangon, M., Le Fur, G., et al. (1995). Enhancement of endotoxin-induced interleukin10 production by SR $31747 \mathrm{~A}$, a sigma ligand. Eur. J. Immunol. 25, 2882-2887.

Bourrie, B., Bribes, E., De Nys, N., Esclangon, M., Garcia, L., Galiegue, S., et al. (2002). SSR125329A, a high affinity sigma receptor ligand with potent anti-inflammatory properties. Eur. J. Pharmacol. 456, 123-131. Bourrie, B., Bribes, E., Derocq, J. M., Vidal, H., and Casellas, P. (2004). Sigma receptor ligands: applications in inflammation and oncology. Curr. Opin. Investig. Drugs 5, 1158-1163.

Bowen, W. D. (2000). Sigma receptors: recent advances and new clinical potentials. Pharm. Acta Helv. 74, 211-218.

Bowen, W. D., Bertha, C. M., Vilner, B. J., and Rice, K. C. (1995). CB64D and CB-184: ligands with high sigma 2 receptor affinity and subtype selectivity. Eur. J. Pharmacol. 278, 257-260.

Bowen, W. D., Walker, J. M., De Costa, B. R., Wu, R., Tolentino, P. J., Finn, D., et al. (1992). Characterization of the enantiomers of cis-N-[2-(3,4dichlorophenyl)ethyl]-N-methyl2-(1- pyrrolidinyl)cyclohexylamine (BD737 and BD738): novel compounds with high affinity, selectivity and biological efficacy at sigma 262, 32-40.

Carayon, P., Bouaboula, M., Loubet, J. F., Bourrie, B., Petitpretre, G., Le Fur, G., et al. (1995). The sigma ligand SR 31747 prevents the development of acute graft-versus-host disease in mice by blocking IFN-gamma and GM-CSF mRNA expression. Int. J. Immunopharmacol. 17, 753-761.

Carr, D. J., De Costa, B. R., Radesca, L., and Blalock, J. E. (1991). Functional assessment and partial characterization of $[3 \mathrm{H}](+)$-pentazocine binding sites on cells of the immune system. J. Neuroimmunol. 35, 153-166. receptors. J. Pharmacol. Exp. Ther.

NF- $\kappa$ B and especially NFAT activation. Nonetheless, our data will not necessarily predict the effects of $\sigma-2$ agonists in vivo, further. Therefore, these data open a new field for the study of $\sigma-2$ ligands as new therapeutic agents in pathologies as inflammatory and autoimmune diseases. In addition, they also open new answers to explore the therapeutic effect of $\sigma-2$ agonists on other diseases where NFAT inhibition may play a pathological role.

\section{ACKNOWLEDGMENTS}

We are grateful to those who have helped us with different reagents as mentioned in Section "Materials and Methods." We also thank María Chorro and María Cazorla for their excellent technical assistance and experimental work. This work was supported by grants from Laboratorios del Dr. ESTEVE S. A and in part by grants from Comunidad Autónoma de Madrid (CAM; S2010/BMD-2332), Cardiovascular RECAVA, and RICET Networks of the Instituto de Salud Carlos III (RD06/0014/1013; RD06/0021/0016), Ministerio de Ciencia e Innovación (SAF2010-18733 to Manuel Fresno), and (BFU2010-21055 and SAF2011-23971 to Miguel A. Iñiguez). The Centro de Biología Molecular Severo Ochoa receives an institutional grant from the Fundación Ramón Areces.

Casellas, P., Bourrie, B., Canat, X. Carayon, P., Buisson, I., Paul, R., et al. (1994). Immunopharmacological profile of SR 31747: in vitro and in vivo studies on humoral and cellular responses. J. Neuroimmunol. 52, 193-203.

Crabtree, G. R. (1999). Generic signals and specific outcomes: signaling through $\mathrm{Ca} 2+$, calcineurin, and NF-AT. Cell 96, 611-614.

Crawford, K. W., Coop, A., and Bowen, W. D. (2002). sigma(2) Receptors regulate changes in sphingolipid levels in breast tumor cells. Eur. J. Pharmacol. 443, 207-209.

DeHaven-Hudkins, D. L., Daubert, J. D., Sawutz, D. G., Tiberio, L., and Baine, Y. (1996). [3H]1,3-di(2tolyl) guanidine binds to a sigma 2 receptor on Jurkat cell membranes, but sigma compounds fail to influence immunomodulatory events in human peripheral blood lymphocytes. Immunopharmacology 35, 27-39.

Derocq, J. M., Bourrie, B., Segui, M., Le Fur, G., and Casellas, P. (1995). In vivo inhibition of endotoxin-induced proinflammatory cytokines production by the sigma ligand SR 31747. J. Pharmacol. Exp. Ther. 272, 224-230.

Duque, J., Fresno, M., and Iniguez, M. A. (2005). Expression and function of the nuclear factor of activated $\mathrm{T}$ cells in colon carcinoma cells: involvement in the regulation of cyclooxygenase-2. J. Biol. Chem. 280, 8686-8693.
Durand, D. B., Bush, M. R., Morgan, J. G., Weiss, A., and Crabtree, G. R. (1987). A 275 basepair fragment at the 5 ' end of the interleukin 2 gene enhances expression from a heterologous promoter in response to signals from the $\mathrm{T}$ cell antigen receptor. J. Exp. Med. 165, 395-407.

Durand, D. B., Shaw, J. P., Bush, M. R., Replogle, R. E., Belagaje, R., and Crabtree, G. R. (1988). Characterization of antigen receptor response elements within the interleukin-2 enhancer. Mol. Cell. Biol. 8, 1715-1724.

Entrena, J. M., Cobos, E. J., Nieto, F. R., Cendan, C. M., Gris, G., Del Pozo, E., et al. (2009). Sigma-1 receptors are essential for capsaicin-induced mechanical hypersensitivity: studies with selective sigma-1 ligands and sigma-1 knockout mice. Pain 143, 252-261.

Gachet, S., and Ghysdael, J. (2009). Calcineurin/NFAT signaling in lymphoid malignancies. Gen. Physiol. Biophys. 28, F47-F54.

Ganapathy, M. E., Prasad, P. D., Huang, W., Seth, P., Leibach, F. H., and Ganapathy, V. (1999). Molecular and ligand-binding characterization of the sigma-receptor in the Jurkat human $\mathrm{T}$ lymphocyte cell line. J. Pharmacol. Exp. Ther. 289, 251-260.

Gannon, C. J., Malone, D. L., and Napolitano, L. M. (2001). Reduction of IL-10 and nitric oxide synthesis by SR31747A (sigma ligand) in RAW murine macrophages. Surg. Infect. (Larchmt) 2, 267-272; discussion 273 . 
Guitart, X., Codony, X., and Monroy, X. (2004). Sigma receptors: biology and therapeutic potential. Psychopharmacology (Berl.) 174, 301-319.

Hanner, M., Moebius, F. F., Flandorfer, A., Knaus, H. G., Striessnig, J., Kempner, E., et al. (1996). Purification, molecular cloning, and expression of the mammalian sigmal-binding site. Proc. Natl. Acad. Sci. U.S.A. 93, 8072-8077.

Hogan, P. G., Chen, L., Nardone, J., and Rao, A. (2003). Transcriptional regulation by calcium, calcineurin, and NFAT. Genes Dev. 17, 2205-2232.

Iniguez, M. A., Martinez-Martinez, S., Punzon, C., Redondo, J. M., and Fresno, M. (2000). An essential role of the nuclear factor of activated $\mathrm{T}$ cells in the regulation of the expression of the cyclooxygenase-2 gene in human Tlymphocytes. J. Biol. Chem. 275, 23627-23635.

Iniguez, M. A., Punzon, C., and Fresno, M. (1999). Induction of cyclooxygenase- 2 on activated $\mathrm{T}$ lymphocytes: regulation of $\mathrm{T}$ cell activation by cyclooxygenase2 inhibitors. J. Immunol. 163, 111-119.

Jimenez, J. L., Iniguez, M. A., MunozFernandez, M. A., and Fresno, M. (2004). Effect of phosphodiesterase 4 inhibitors on NFATdependent cyclooxygenase- 2 expression in human $\mathrm{T}$ lymphocytes. Cell. Signal. 16, 1363-1373.

Kiani, A., Rao, A., and Aramburu, J. (2000). Manipulating immune responses with immunosuppressive agents that target NFAT. Immunity $12,359-372$.

Kvaratskhelia, E., Maisuradze, E., Dabrundashvili, N. G., Natsvlishvili, N., Zhuravliova, E., and Mikeladze, D. G. (2009). N-methyl-D-aspartate and sigma-ligands change the production of interleukins 8 and 10 in lymphocytes through modulation of the NMDA glutamate receptor. Neuroimmunomodulation 16, 201-207.

Liu, Y., Whitlock, B. B., Pultz, J. A., and Wolfe, S. A. Jr. (1995). Sigma-1 receptors modulate functional activity of rat splenocytes. J. Neuroimmunol. 59, 143-154.

Mao, J. T., Zhu, L. X., Sharma, S., Chen, K., Huang, M., Santiago, S. J., et al. (1997). Cocaine inhibits human endothelial cell IL-8 production: the role of transforming growth factorbeta. Cell. Immunol. 181, 38-43.

Mao, X. W., Archambeau, J. O., and Gridley, D. S. (1996). Immunotherapy with low-dose interleukin-2 and a polysaccharopeptide derived from Coriolus versicolor. Cancer Biother. Radiopharm. 11, 393-403.

Martinez-Martinez, S., and Redondo, J. M. (2004). Inhibitors of the calcineurin/NFAT pathway. Curr. Med. Chem. 11, 997-1007.

Matsumoto, R. R., Bowen, W. D., Tom, M. A., Vo, V. N., Truong, D. D., and De Costa, B. R. (1995). Characterization of two novel sigma receptor ligands: antidystonic effects in rats suggest sigma receptor antagonism. Eur. J. Pharmacol. 280, 301-310.

Matsumoto, R. R., Shaikh, J., Wilson, L. L., Vedam, S., and Coop, A. (2008). Attenuation of methamphetamineinduced effects through the antagonism of sigma (sigma) receptors: evidence from in vivo and in vitro studies. Eur. Neuropsychopharmacol. $18,871-881$.

Mattana, J., Gibbons, N., and Singhal, P. C. (1994). Cocaine interacts with macrophages to modulate mesangial cell proliferation. J. Pharmacol. Exp. Ther. 271, 311-318.

Megalizzi, V., Le Mercier, M., and Decaestecker, C. (2010). Sigma receptors and their ligands in cancer biology: overview and new perspectives for cancer therapy. Med. Res. Rev. 32, 410-427.

Mir, S. U., Ahmed, I. S., Arnold, S., and Craven, R. J. (2012). Elevated progesterone receptor membrane component $1 /$ sigma- 2 receptor levels in lung tumors and plasma from lung cancer patients. Int. J. Cancer 131, E1-E9.

Ndiaye, K., Poole, D. H., Walusimbi, S., Cannon, M. J., Toyokawa, K., Maalouf, S. W., et al. (2012). Progesterone effects on lymphocytes may be mediated by membrane progesterone receptors. J. Reprod. Immunol. 95, 15-26.

Pellegrino, T., and Bayer, B. M. (1998). In vivo effects of cocaine on immune cell function. J. Neuroimmunol. 83, 139-147.

Rao, A., Luo, C., and Hogan, P. G. (1997). Transcription factors of the NFAT family: regulation and function. Annu. Rev. Immunol. 15, 707-747.
Rhoades, K. L., Golub, S. H., and Economou, J. S. (1992). The regulation of the human tumor necrosis factor alpha promoter region in macrophage, $\mathrm{T}$ cell, and $\mathrm{B}$ cell lines. J. Biol. Chem. 267, 22102-22107.

Rossi, D., Pedrali, A., Urbano, M., Gaggeri, R., Serra, M., Fernandez, L., et al. (2011). Identification of a potent and selective sigma(1) receptor agonist potentiating NGF-induced neurite outgrowth in PC12 cells. Bioorg. Med. Chem. 19, 6210-6224.

San-Antonio, B., Iniguez, M. A., and Fresno, M. (2002). Protein kinase Czeta phosphorylates nuclear factor of activated $\mathrm{T}$ cells and regulates its transactivating activity. J. Biol. Chem. 277, 27073-27080.

Su, T. P., and Hayashi, T. (2003). Understanding the molecular mechanism of sigma-1 receptors: towards a hypothesis that sigma-1 receptors are intracellular amplifiers for signal transduction. Curr. Med. Chem. 10 2073-2080.

Su, T. P., London, E. D., and Jaffe, J. H. (1988). Steroid binding at sigma receptors suggests a link between endocrine, nervous, and immune systems. Science 240, 219-221.

Su, T. P., Wu, X. Z., Cone, E. J., Shukla, K., Gund, T. M., Dodge, A. L., et al. (1991). Sigma compounds derived from phencyclidine: identification of PRE-084, a new, selective sigma ligand. J. Pharmacol. Exp. Ther. 259 543-550.

Ullman, K. S., Northrop, J. P., Verweij, C. L., and Crabtree, G. R. (1990). Transmission of signals from the $\mathrm{T}$ lymphocyte antigen receptor to the genes responsible for cell proliferation and immune function: the missing link. Annu. Rev. Immunol. 8 421-452.

van Waarde, A., Rybczynska, A. A. Ramakrishnan, N., Ishiwata, K., Elsinga, P. H., and Dierckx, R. A. (2010). Sigma receptors in oncology: therapeutic and diagnostic applications of sigma ligands. Curr. Pharm. Des. 16, 3519-3537.

Vilner, B. J., and Bowen, W. D (2000). Modulation of cellular calcium by sigma-2 receptors: release from intracellular stores in human SK-N-SH neuroblastoma cells. $J$. Pharmacol. Exp. Ther. 292, 900-911.

Viola, J. P., Carvalho, L. D., Fonseca, B. P., and Teixeira, L. K. (2005). NFAT transcription factors: from cell cycle to tumor development. Braz. J. Med. Biol. Res. 38, 335-344.

Weiss, A., and Littman, D. R. (1994). Signal transduction by lymphocyte antigen receptors. Cell 76, 263-274.

Wolfe, S. A. Jr., Kulsakdinun, C., Battaglia, G., Jaffe, J. H., and De Souza, E. B. (1988). Initial identification and characterization of sigma receptors on human peripheral blood leukocytes. J. Pharmacol. Exp. Ther. 247, 1114-1119.

Xu, J., Zeng, C., Chu, W., Pan, F., Rothfuss, J. M., Zhang, F., et al. (2011) Identification of the PGRMC1 protein complex as the putative sigma-2 receptor binding site. Nat. Commun. 2, 380.

Xu, W., Flick, T., Mitchel, J., Knowles, C., and Ault, K. (1999). Cocaine effects on immunocompetent cells: an observation of in vitro cocaine exposure. Int. J. Immunopharmacol. 21, 463-472.

Zhu, L. X., Sharma, S., Gardner, B., Escuadro, B., Atianzar, K., Tashkin, D. P., et al. (2003). IL10 mediates sigma 1 receptordependent suppression of antitumor immunity. J. Immunol. 170, 3585-3591.

Conflict of Interest Statement: Javier Burgueño and José M. Vela are employes of Laboratories ESTEVE, which partially funded this research.

Received: 15 November 2012; accepted: 18 February 2013; published online: 13 March 2013.

Citation: Iñiguez MA, Punzón C, Nieto $R$, Burgueño J, Vela JM and Fresno $M$ (2013) Inhibitory effects of sigma2 receptor agonists on $T$ lymphocyte activation. Front. Pharmacol. 4:23. doi: 10.3389/fphar.2013.00023

This article was submitted to Frontiers in Inflammation Pharmacology, a specialty of Frontiers in Pharmacology.

Copyright (c) 2013 Iñiguez, Punzón, Nieto, Burgueño, Vela and Fresno. This is an open-access article distributed under the terms of the Creative Commons Attribution License, which permits use, distribution and reproduction in other forums, provided the original authors and source are credited and subject to any copyright notices concerning any third-party graphics etc. 